\title{
An Account of the Scientific Work of the Northumber- land Sea Fisheries Committee.
}

\author{
By \\ Alexander Meek, M.Sc., F.Z.S. \\ The Durham College of Science, Newcastle-on-Tyne.
}

JUst as a small marine laboratory is being fitted up at Cullercoats, it may be desirable to present to a wider audience a short account of the scientific work already done-work which has, in fact, given origin to the building now almost ready for occupation. As regards the laboratory, a word may be said. It is small, but it will be provided with a tank-room and the essential requirements for carrying on, at any rate, biological investigations. The tanks are made of wood, and will be supplied by gravitation in succession. At the same time a series of glass cylinders can be added in any number, and supplied with sea water in a similar manner. The workroom is very cheery, well lighted and well ventilated, and will accommodate six or even more workers. We are indebted for this most desirable adjunct to the biological department of the College to the ViceChairman of the Committee, who has already done so much for local fishery questions. The laboratory will, we hope, not only help in the development of our biological work, but form a centre for enquiry, and thus take a share in the general work of investigation now going on in this country.

It owes its inception, in fact, to the contributions to this work already made by the Committee. The trawling excursions conducted by Mr. Dent were begun in 1892, and have been continued in successive years since. Mr. Dent can remember when he could get as many as ten fine turbot with a harpoon any night on Blyth Beach (1860-65); at which period, also, he could almost fill a boat with the fish caught in a small drift-net. He witnessed the depletion of these and other bays which occurred after the steam-trawlers commenced to fish in the district (1877). He has seen the consequent 
great development of North Shields, and the decline of the ordinary fisheries in the smaller villages and towns.

The three-mile restriction was adopted in 1891, and with the view of ascertaining how far this was to be valuable in restoring the fish to the bays along the coast, Mr. Dent kindly placed one of his steamers at the disposal of the Committee, and personally superintended the expeditions. The trawl used is an ordinary one of twenty-two feet beam, and a day of eight to nine hours is devoted to each bay.

The results have previously been published in yearly tables for the information of the Committee, but it will be more valuable for our present purpose to give the results for each bay. They are interesting in that these bays lie side by side, or, at any rate, within a district of forty miles; they are near to the stations of the similar but naturally more elaborate Scottish experiments, and it seems, from Dr. Fulton's investigations on currents, that we should get our supplies from the spawning grounds of the north. There is no necessity, however, of dwelling upon the results. A glance over each of the following tables shows only too plainly that the bye-law has made little improvement in the numbers of the mature fish. It ought to have been stated that the gurnards were not counted in the first two years. Blyth Bay does show an increase in all kinds, practically. Cambois Bay shows an improvement also as regards turbot, soles, dabs, and gurnards, but the plaice have decreased, though they seem again to be improving in numbers. It would be hard to point to any change occurring in regard to the fish of Druridge Bay. The numbers remain very steady for each year. The increase in the plaice of Alnmouth Bay is very marked. Soles are also increasing. Dabs scarcely show any change. In Skate Roads turbot and soles seem to give better returns, but plaice have decreased. It will be noted that flounders are not recorded for 1895 , but it is highly probable that a few occurred and were overlooked, for they are very characteristic of this bay.

The undersized fish were taken particular note of at last year's excursions. By this term is meant such fish as were caught in the trawl and too small to be retained.* At Alnmouth Bay, on the 23rd July, they were roughly counted after the first haul before being returned to the sea. There were some 20 flounders of 6 in. or less; some 25 plaice of 7 in. or less; and 12 gurnards 8 in. or less. It was calculated that quite 100 immature fish were returned to the sea at each haul. It is the custom at these excursions to return the fish which are not

\footnotetext{
* It may be a rough classification, this, into mature or saleable, and immature or undersized; but in our anxiety to return the small fish as quickly as possible we do not as a rule make measurements, or even always count them.
} 
retained as quickly as possible, and in every case it is noted that the flat fish swim away at once, evidently little the worse for being dragged along with the trawl for often two or even three hours, their visit to the deck of the steamer, and being swept overboard.

Druridge Bay possesses many young dabs and plaice. Skate Roads is rich in young flounders and plaice, and small turbot and brill are got as well. Cambois and Blyth Bays have principally immature dabs, but soles, flounders, and gurnards occur also in this category.

It is quite evident, then, that the restriction is useful in the protection it affords to valuable fish in the immature condition. But there is a curious dissimilarity often in the proportions of young and mature, or, let us say, saleable fish. The latter give us variable returns, sometimes slightly increasing, sometimes slightly decreasing, from year to year. There is no doubt at all that the in-shore trawling of the first few years did make such severe inroads as to be quite apparent. Allowing for seasonal variation in the numbers, there has not been such a return of the mature or large fish as to justify us in saying that the bye-law in that respect was tending to much good. If we now compare the rough statistics we have for Alnmouth Bay in regard to the immature fish with that part of the table referring to 1896, and assuming that the trawl was down five times at each excursion, the immature flounders would have been, say, 100. We only got three saleable. The immature dabs would be, say, 150. We got about half that number large enough to keep. The immature plaice would be 125 , which is below the number of matured forms retained, and this in a bay showing an increase in the saleable plaice. I cannot speak as to the immature fish in previous years; but these figures, which could be repeated for the other bays, show only too well that a large destruction of fish occurs somewhere before they become mature. That this occurs when they go out to spawn seems from the collateral evidence of other experiments only too likely. Either this is the case or many of them depart after their in-shore early life and never return. But this does not explain the practical non-increase in these and other similar territorial waters. These facts only add to the evidence in regard to the destruction of the spawners outside the limits.

The plaice last year varied from 12 to 16 or 17 ins. in total length (one example measured $19 \frac{3}{4}$ by $11 \frac{1}{2}$ ins., fins included), and were feeding principally on Donax trunculus, which is extremely common in these bays. Tellina tenuis and Venus gallina also occurred in some of the stomachs examined. The dabs measured 9 to 13 ins. in length, and were feeding mainly on Portunus holsatus, and sometimes old and fresh shells of various mollusca were found in the stomach as well. The soles were got from 12 to 20 ins., and sandeels were found most often in the stomachs. 
Turbots also varied from 12 to 20 ins., and were found to feed on small whitings, the lesser weever, and the sandeel. Brill of $14 \frac{1}{2}$ and $20 \frac{1}{2}$ ins. were feeding on whitings. Flounders (12 to 18 ins.) had Donax trunculus, sandeels, Mactra stultorum, Tellina tenuis, Portunus holsatus as the forms found in the stomachs of a few examples. The common gurnard of 11 to 16 ins. was feeding on sandeels, whitings, Portunus holsatus, etc. Other forms were investigated, and full details of measurements and contents of stomachs are given in last year's report. The more important "other fish," etc., are also referred -to.

The surface nets gave us two kind of eggs-those of the Lesser Weever (Trachinus vipera) and an unknown egg not differing from McIntosh and Prince's "F" form.

Mr. Gregg Wilson, of Edinburgh University, while in the district, made investigations into the condition of the crab, lobster, and mussel fisheries. He found evidence which led him to suppose that crabs spawn during November, December, and January; that females were not less than $6 \mathrm{in}$. when mature, that males were mature at $5 \mathrm{in}$. Along with a close time, which is, however, commonly naturally given during these months, he recommended the raising of the size-limit to $5 \mathrm{in}$. He recommended also a close time for lobsters during June and July, on the assumption that in these months most berried hens were found. The sale of the berried hen, it is expected, will shortly, however, be prohibited in the district.

A member of the Committee, Mr. William King, who has had much experience in mussel cultivation, contributed an interesting paper on that subject. A list of the papers published for the information of the Committee is appended.

We have to remember also the rich inheritance of local zoological work we have from such eminent naturalists as Dr. Johnston, Joshua Alder, Albany Hancock, Dr. G. S. Brady, Dr. H. B. Brady, the Rev. Canon Norman, R. Howse, and others.

\section{List of Papers Published by the Committee.}

1. 1891. William King-"Mussels and Mussel Culture."

2. 1893. Gregg Wilson, M.A., B.Sc.--" Report on the Crab, Lobster, and Mussel Fisheries of Northumberland."

3. 1895. C. Williams - "Report of a Visit of the Northumberland Sea Fisheries Committee to the Marine Hatchery at Dunbar."

4. 1895. Gregg Wilson, B.Sc., Ph.D.- "Further Report on the Crab Fishery."

5. 1895. John Dent, J.P.- "Records of Scientific Trawling Operations conducted off the Northumberland Coast (1892-95).

6. 1896. Alexander Meek, B.Sc., F.Z.S.- " Report on the Scientific Results of the Trawling Expeditions carried on by the Northumberland Sea Fisheries Committee during the Summer of 1896." 


\section{Tables showing the number of Fish captured in each Bay.}

(1) Blyth Bay. 2-5 Fathoms.

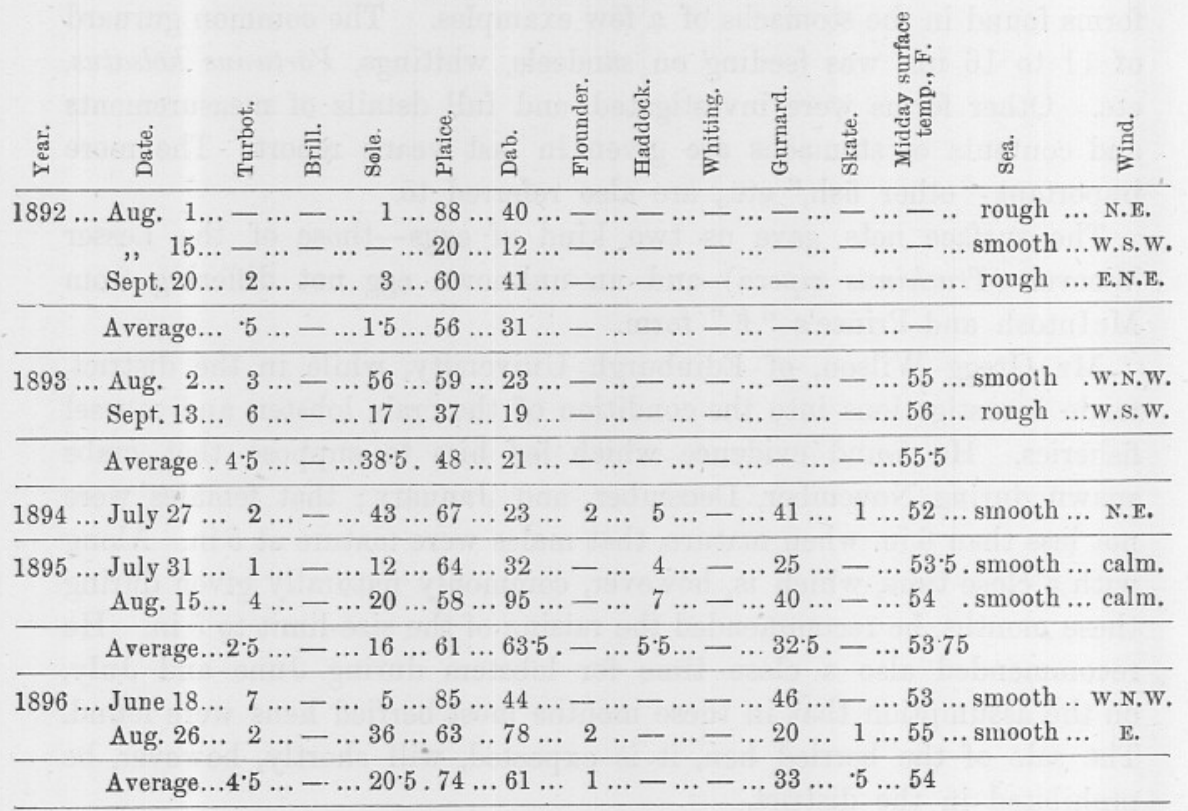

(2) Cambois Bay. Depth 3-7 Fathoms.

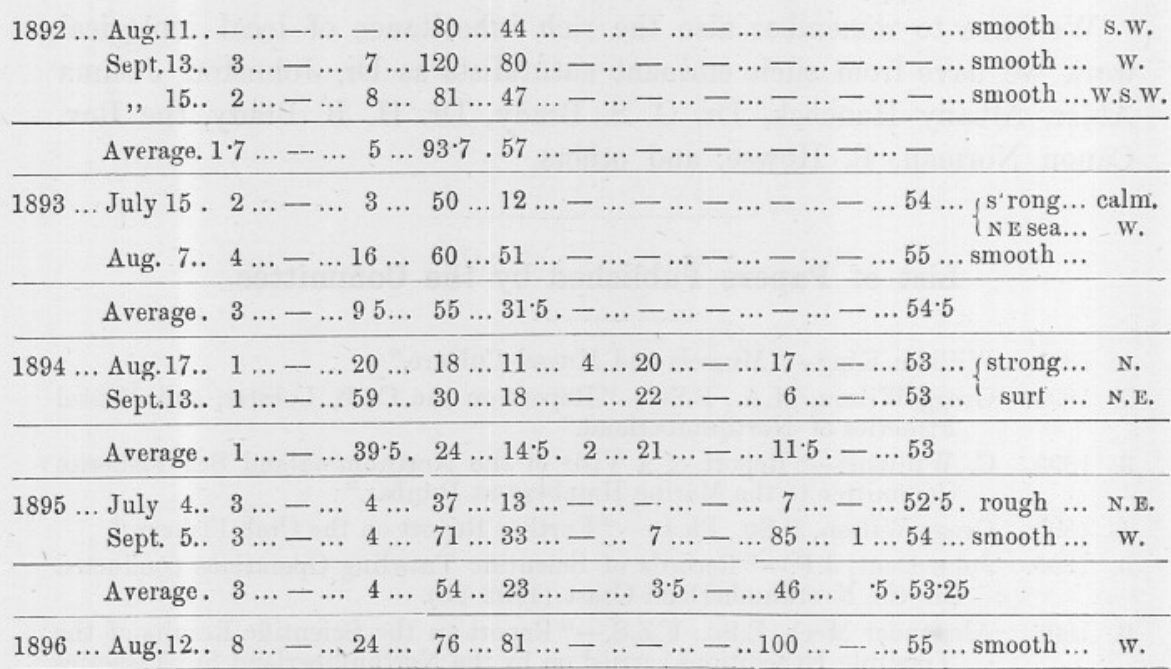


(3) Druridge Bay. 2-3 Fathoms.

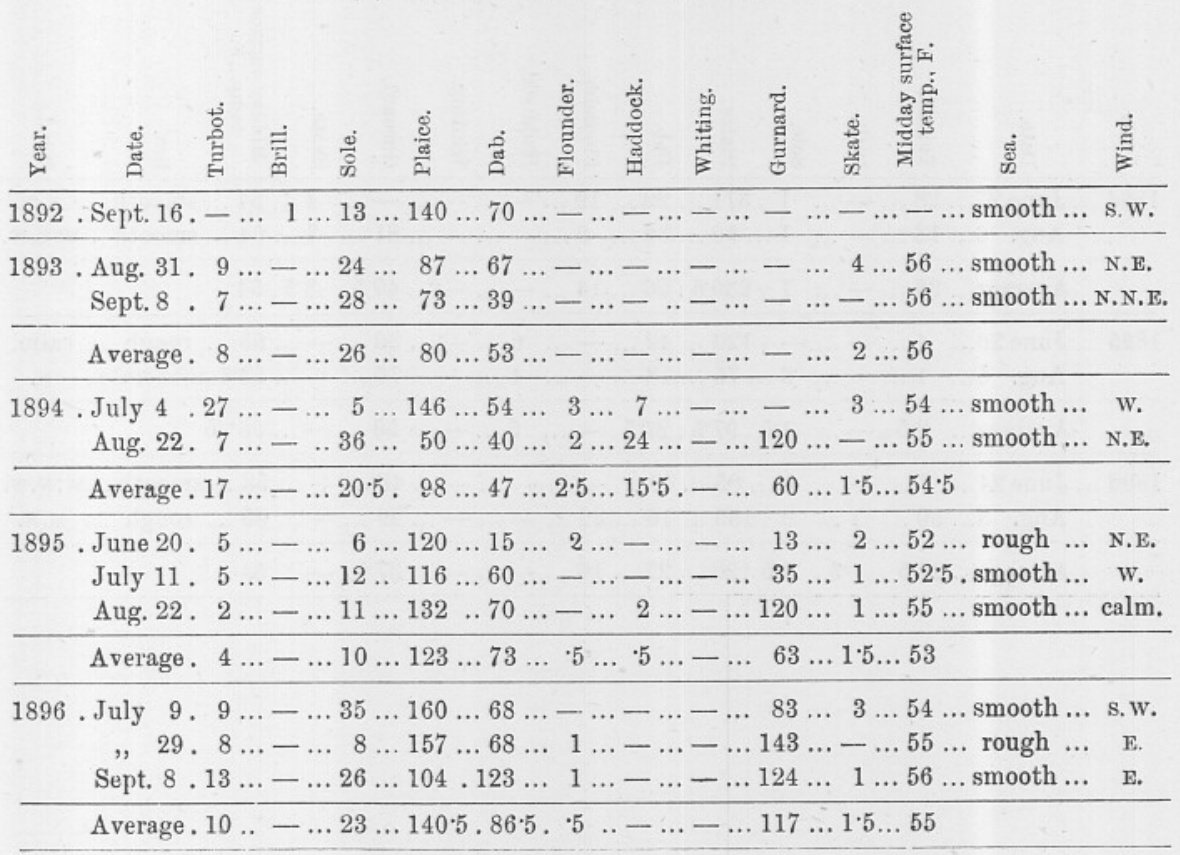

(4) Alnmouth Bay. Depth 2-3 Fathoms.

1893 . July 25. $9 \ldots-\ldots 8 \ldots 116 \ldots 100 \ldots-\ldots-\ldots-\ldots-\ldots 4 \ldots 54 \ldots$ smooth $\ldots$ N.w. Aug. 22. $3 \ldots-\ldots 11 \ldots 75 \ldots 49 \ldots-\ldots-\ldots-\ldots-\ldots 1 \ldots 55 \ldots$ smooth $\ldots$ s. s. w. Average. $6 \ldots-\ldots 9 \cdot 5.95 \cdot 5.745 .-\ldots-\ldots-\ldots-\ldots 2.5 .54 \cdot 5$

1894 . July $11.17 \ldots-\ldots 5 \ldots 131 \ldots 63 \ldots 14 \ldots 2 \ldots-\ldots 49 \ldots 3 \ldots 52 \ldots$ smooth $\ldots$ v.e. ,$\quad 31.8 \ldots-\ldots 18 \ldots 60 \ldots 51 \ldots 4 \ldots 12 \ldots-\ldots 17 \ldots 3 \ldots 54 \ldots$ smooth $\ldots$ calm. Aug. $29.14 \ldots-\ldots 8 \ldots 65 \ldots 35 \ldots 7 \ldots 15 \ldots-\ldots 85 \ldots 2 \ldots 55 \cdot 5$. smooth $\ldots \quad$ w.

Average. $13 \ldots-\ldots 10 \cdot 5.855 .50 \ldots 8 \cdot 5.10 \ldots-\ldots 505.3 \ldots 54$

1895 . July $25,7 \ldots-\ldots 4 \ldots 118 \ldots 82 \ldots-\ldots 10 \ldots-\ldots 24 \ldots-\ldots 52 \ldots$ smooth $\ldots$ N.E. Aug. 29. $3 \ldots-\ldots 7 \ldots 101 \ldots 46 \ldots-. .103 \ldots-\ldots 65 \ldots 1 \ldots 54 \ldots$ moderate . w.

Average. $5 \ldots-\ldots 5 \cdot 5.109 \cdot 5.64 \ldots-\ldots 56 \cdot 5 . \ldots 44 \cdot 5 . \quad \cdot 5.53$

1896 . July $23.13 \ldots-\ldots 30 \ldots 202 \ldots 117 \ldots 3 \ldots 2 \ldots 1 \ldots 29 \ldots 1 \ldots 55 \ldots$ smooth $\ldots$ w. Aug. 19. $9 \ldots 1 \ldots 9 \ldots 154 \ldots 44 \ldots 3 \ldots-\ldots-\ldots 46 \ldots-\ldots 55 \ldots$ smooth..$\quad$ N.

$\begin{array}{lllllllll}\text { Average. } 11 \ldots & \cdot 5.19 \cdot 5.178 \ldots & 80 \cdot 5 . & 3 \ldots & 1 \ldots & 5.37 \cdot 5 . & 5.55\end{array}$ 


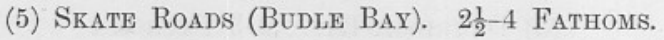

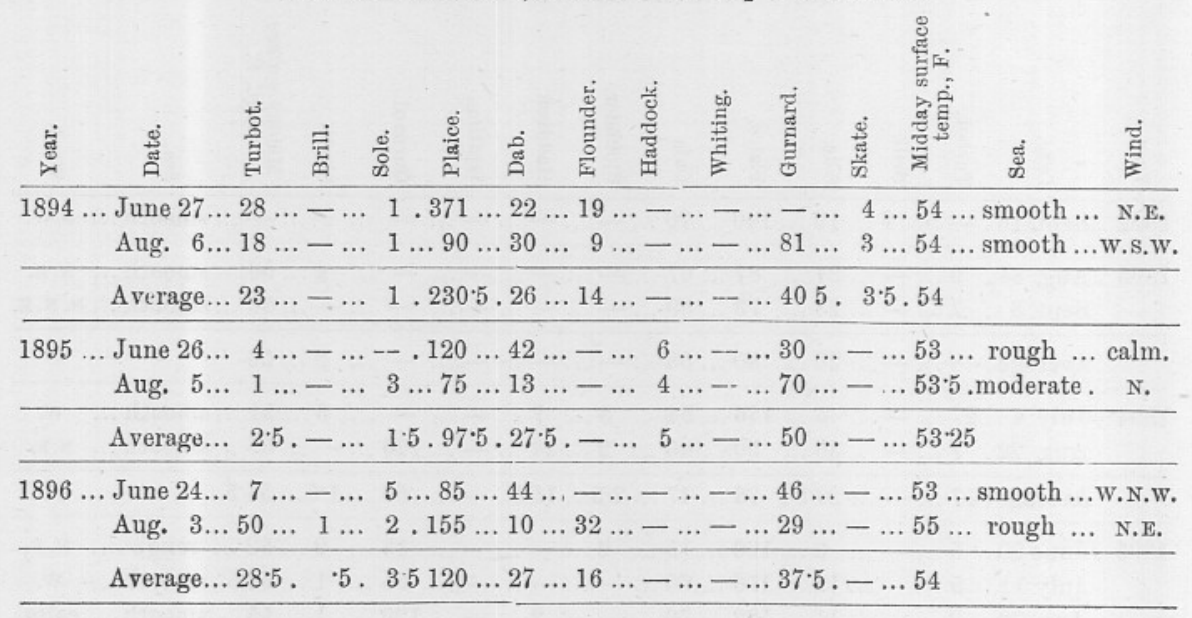

